\title{
Can stigma become a resource? The mobilisation of aesthetic-corporal capital by female immigrant entrepreneurs from Brazil
}

\author{
Jorge Malheiros and Beatriz Padilla
}

(Received 14 January 2013; final version received 21 May 2014)

\begin{abstract}
The proportion and visibility of Brazilian women and particularly the specific images of Brazil and Brazilians in the Portuguese imaginary have contributed to the construction of new versions of stigma and stereotypes surrounding them. Mainstream images of Brazilian women have incorporated prejudices about the sensuality of Creole women who are reminiscent of the Portuguese colonial imaginary. Starting from this stigmatised image, we show how Brazilian women entrepreneurs in the 'beauty' business filière reinterpret and mobilise this perceived negative image, transforming it into an added value associated with an 'aesthetic' Brazilian body culture. This idea of 'body' aesthetics becomes a business resource transformed into aestheticcorporal capital, a key component of the Brazilian beauty business filière. Empirically, this research is based on qualitative elements, in particular 25 interviews with Brazilian women entrepreneurs of the beauty filière working in Portugal, collected for the project BELTS-W (Brazilian Entrepreneurial Links and Transnational Strategies - Women).
\end{abstract}

Keywords: Brazilian immigrants; female entrepreneurs; stereotypes; colonial imaginary; aesthetic-corporal capital; beauty filière

\section{Introduction}

Although research on immigrant women is more recent than migration studies, the progress made since Morokvasic's (1984) pioneering work Birds of Passage Are Also Women, drawing attention to the lack of theories and data on female migration, has been fast and intense. However, most studies have concentrated on the precarious conditions of migrant women's lives, locating them 'in serviceoriented sectors that are largely black economies that reproduce the gender, class, and ethnic divides' (Pajnik and Campani 2011, 9).

Until recently, the field of female immigrant entrepreneurship had been overlooked, with some exceptions (Ribas-Mateos and Oso 2005; Dallalfar 1994; Menjívar 1999; Serdedakis et al. 2003; Pearce 2005; Levent and Nijkamp 2006; Padilla 2008). Critical perspectives countering the gender-blindness analyses of immigrant entrepreneurialism, often based on a non-explicit naturalising of male features (i.e. propensity to risk-taking, 'outside life'/contact 
with the public, time flexibility) supposedly conducive to setting up and developing businesses, have recently emerged. This line of research has underlined host societies' significant discrimination against women immigrants in terms of providing them with access to information and formal structures (e.g. banks, financing sources), because they tend to associate women's status as foreigners with limited business resource channels and smaller amounts of independently owned economic capital (Levent and Nijkamp 2006). Some studies also suggest that immigrant women experience particular difficulties in enlarging their social networks, which are often more family-centred and less institutionalised than male networks (Anthias and Mehta 2003; Malheiros, Padilla, and Rodrigues 2010), and in negotiating changes in their traditional gender roles when starting a business (Levent, Masurel, and Nijkamp 2003). Frequently, the solutions to overcoming these barriers result in family conflict or the development of new dependencies on male family members, who become business associates, formal partners (even if the business is de facto run by women) or 'simply' business sponsors (Ionescu 2004).

Despite these constraints, starting up a business may have very positive impacts for women, not only because their income tends to experience a higher relative increase when compared to men's but also because entrepreneurship paves the way to more flexible time management, thereby facilitating the articulation between family life and work, contributing to enlarging social networks and increasing self-esteem and self-confidence (Rodrigues, Padilla, and Malheiros 2011).

Taking into account the aforementioned constraints and strategies of immigrant women entrepreneurs, this article aims to demonstrate how a specific form of capital - aesthetic-corporal capital - is mobilised, becoming a key asset for women immigrant businesses in a specific activity sector. Specifically, it is intended to illustrate how Brazilian women entrepreneurs who are immigrants in Portugal mobilise and reconstruct stereotypes and attributes that Portuguese society has historically assigned to them (the 'provocative' sexual attitude that goes back to the colonial imaginary regarding the sensuality, 'availability' and beauty of mulata women), namely in the domain of body culture, as resources that facilitate the starting up and development of businesses in what we have named the beauty filière.

In order to do this, we describe firstly the methodology employed for the empirical research on which our arguments are based, together with background information on the evolution of Brazilian immigration in Portugal within the context of growing feminisation detected in recent years. Reference is also made to the nature of self-employment among Brazilian women in Portugal and their specialisation in the beauty sector.

Secondly, we analyse the beautification embedded in female immigrants' business, discussing the concept of aesthetic-corporal capital and emphasising, based on the results of our fieldwork, immigrants' strategies as well as the specificities of Brazilian-owned businesses of the beauty filière in Portugal. 
Some strategies and specificities arise from general global issues (women's preference for these types of businesses, relatively limited initial investment), whilst others are consequences of the specific gendered position and status that Brazilian women hold in Portugal. Thus, gender theories on intersectionality and coloniality help to understand how social inequalities shape the migrant experience in multidimensional ways, allowing some female immigrants, in this case Brazilian entrepreneurs, to partially overcome discrimination by mobilising the imaginary of colonial sensual femininity in order to create a business niche. This view provides a new twist that contributes theoretically to the body of studies about female entrepreneurship, highlighting how negative stereotypes, on certain occasions, provide opportunities in business settings and labour markets. However, it should be noted that this approach does not adopt a feminist perspective as issues of power and asymmetry (e.g. between Portuguese women and Brazilian men) are not fully taken into account.

\section{Brazilian women entrepreneurs in Portugal}

\subsection{Methodological elements}

The case study that empirically sustains our analysis is based on qualitative material collected in interviews within the framework of project BELTS-W (Brazilian Entrepreneurial Links and Transnational Strategies - Women). This project focused on Brazilian women entrepreneurs in Portugal and their business initiatives. It addressed four key issues: (1) the identification of the conditions for the business set-up and development, (2) the implication of entrepreneurship in gender and power relations, (3) the contribution of these entrepreneurial initiatives to local changes and (4) the identification of eventual transnational links between Portugal and Brazil associated with these initiatives.

From the material collected in 88 semi-structured interviews with Brazilian women (48 entrepreneurs of various branches of activity and 40 Brazilian workers with the purpose of exploring their attitudes towards entrepreneurial initiatives), we selected 25 interviews that involved businesswoman in the beauty filière. These interviews were conducted between June 2010 and July 2011 by Portuguese and Brazilian researchers who also transcribed them. It is an illustrative sample of Brazilian women entrepreneurs in Portugal that took as reference the distribution of Brazilian independent workers by branches of activity and regions of settlement presented in secondary sources, namely two previous surveys of Brazilians in Portugal - the questionnaire of the project Vagas Atlanticas $^{1}$ applied to 1200 Brazilians in 2008/2009 and the questionnaire of the Project Women Migrant Entrepreneurs in Portugal, involving 113 Brazilian businesswoman and also conducted in 2009 (Malheiros, Padilla, and Rodrigues 2010). The questionnaires were applied in those regions with the largest concentration of Brazilians (the Lisbon Metropolitan Area, the North Littoral and the Algarve) and in two medium-sized cities of the Centre of 
Portugal (Figueira da Foz and Leiria) where visible clusters of Brazilians were identified.

Narrative extracts have been taken from the analysis of the aforementioned 25 semi-structured interviews with Brazilian entrepreneurs of the beauty filière, mainly from the sections on stigma perception, representation of Brazilian beauty and Brazilian specific competences, Brazilian liveliness and perceived impacts of involvement in business.

\subsection{General contextual elements: expansion and feminisation of Brazilian immigration to Portugal}

Mirroring other Southern European countries, the shift from emigration to immigration began in Portugal in the early 1990s, turning it progressively into a country of immigration at the turn of the twenty-first century (Esteves 1991; Fonseca et al. 2002). Migration flows intensified substantially between 1999 and 2007, from approximately 200,000 people to almost 450,000 (Figure 1), resulting in new trends - mainly feminisation - and the diversification of the countries of origin. During this period, inflows of Brazilian immigrants intensified significantly, accounting for more than $90 \%$ of the total increase of South American and Caribbean migration to Portugal (Figure 1); moreover, new Brazilian migration registered a series of changes in relation to the features registered in the inflows

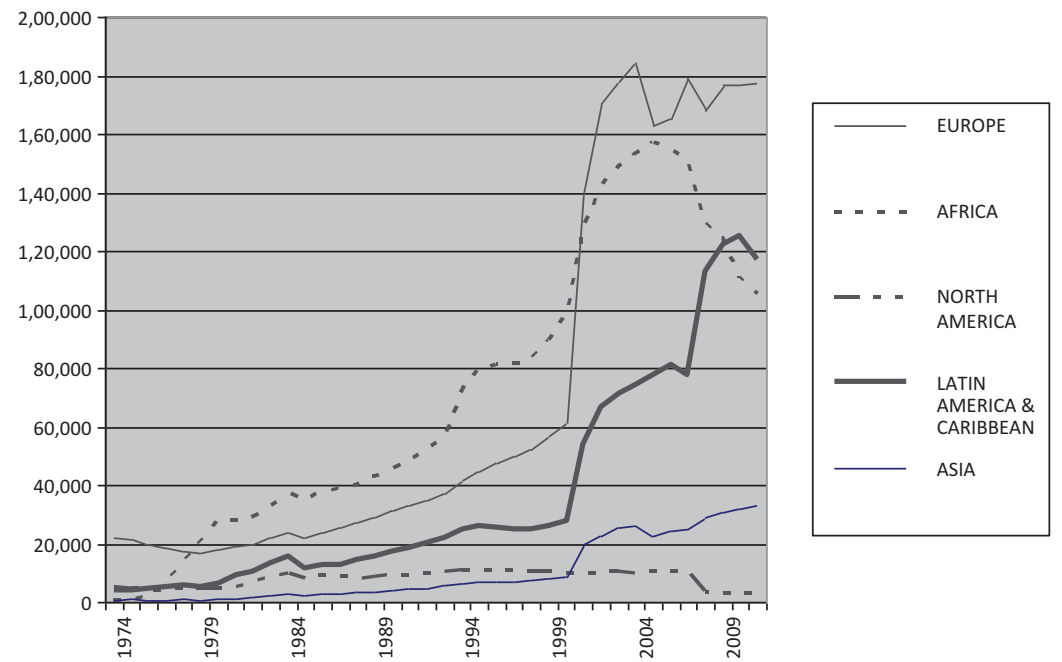

Figure 1. Evolution of the foreign population by continents of origin - 1974-2010. Source: INE, Demographic Yearbook (various years) and Foreigners and Borders Office (SEF). 
of the late 1980s and early 1990s, namely a higher social diversity and growing feminisation (Malheiros 2007).

Nowadays, Brazilians constitute the largest foreign national group residing in Portugal, accounting for approximately $25 \%$ of the total number of foreigners (SEF 2012).

The feminisation of immigration has continued in recent years, although labour migration has been largely replaced by family reunion. In fact, after 2008 , the majority of the new residence permits issued have been granted to women, contributing to the feminisation of the global stock of foreigners, where women represent over $50 \%$ of the total (SEF 2012). This proportion is higher among Brazilians, where women account for $58 \%$ of the total.

From the standpoint of female entrepreneurship, Brazilians in Portugal represent an interesting case study due to their size, evolution and feminisation trends as well as the relatively high rate of entrepreneurship in comparison with several other important immigrant groups settled in the country, namely citizens from PALOP countries and Eastern Europeans (Oliveira 2005; Malheiros, Padilla, and Rodrigues 2010).

\subsection{Gender lenses on Brazilian entrepreneurship in Portugal and the beauty filière}

Very few studies into migration and entrepreneurship in Portugal have analysed gender issues or female participation (Oliveira 2005, 2008; Peixoto 2008; Malheiros 1997). Padilla (2008) attempted to incorporate gender analysis by criticising the lack of a focus on gender in studies of immigrant entrepreneurship, using global inequalities as the starting point and including race, ethnicity, gender, social class and immigrant status as relevant aspects. In addition, the context and characteristics of the host society were identified as elements that encourage or discourage immigrant business activities. Padilla also pointed out how niches and business opportunities vary according to the country of destination as well as to the resources immigrants are able to bring together.

A study by Malheiros, Padilla, and Rodrigues (2010) identified the most salient features of female immigrant entrepreneurship in Portugal among the main immigrant groups: Brazilians, Africans from the PALOP (African countries where Portuguese is the official language) and non-EU Eastern Europeans. This study, based on surveys and focus groups, suggested that immigrant women face more difficulties in accessing credit, clients and distributors than their male counterparts, yet still prefer to set up their own businesses. This is because women perceive business ownership as a better option through which to reconcile work and family life, reach higher levels of empowerment and selfesteem and extend their social networks. In addition, our data indicate that the income differentials favouring Brazilian immigrant women entrepreneurs over women employees are relevant and have a higher relative impact than the 
income differentials between Brazilian male entrepreneurs and Brazilian male employees.

Even though the majority of Brazilians are employees (more than $70 \%$ ), the number of employers and independent workers is quite significant within the global context of immigration. Malheiros, Padilla, and Rodrigues (2010) drew up a profile of female immigrant entrepreneurs, identifying key economic sectors in which opening a business is more common among women. The niche which the study termed the beauty sector in strictu sensu (hair salons, spas, nail treatments, manicure/pedicure and body treatments) encompassed $37 \%$ of all businesses. The retail and trade sector stood at almost $20 \%$, hospitality and catering at $18 \%$ and others (mainly support for domestic work) at $8 \%$. In the case of Brazilian women entrepreneurs, the beauty sector was also dominant, but the percentage (34\%) was slightly below the overall proportion due to the higher overrepresentation of PALOP women entrepreneurs, a group which registers a high concentration specifically in hairdressing.

Nevertheless, the specialisation of Brazilian women in the strictu sensu beauty sector becomes more relevant if entrepreneurial options are considered and compared with salaried workers, and if the beauty sector is redefined. Figure 2 shows a far greater presence of Brazilian female entrepreneurs in personal services and activities that include the strictu sensu beauty sector,

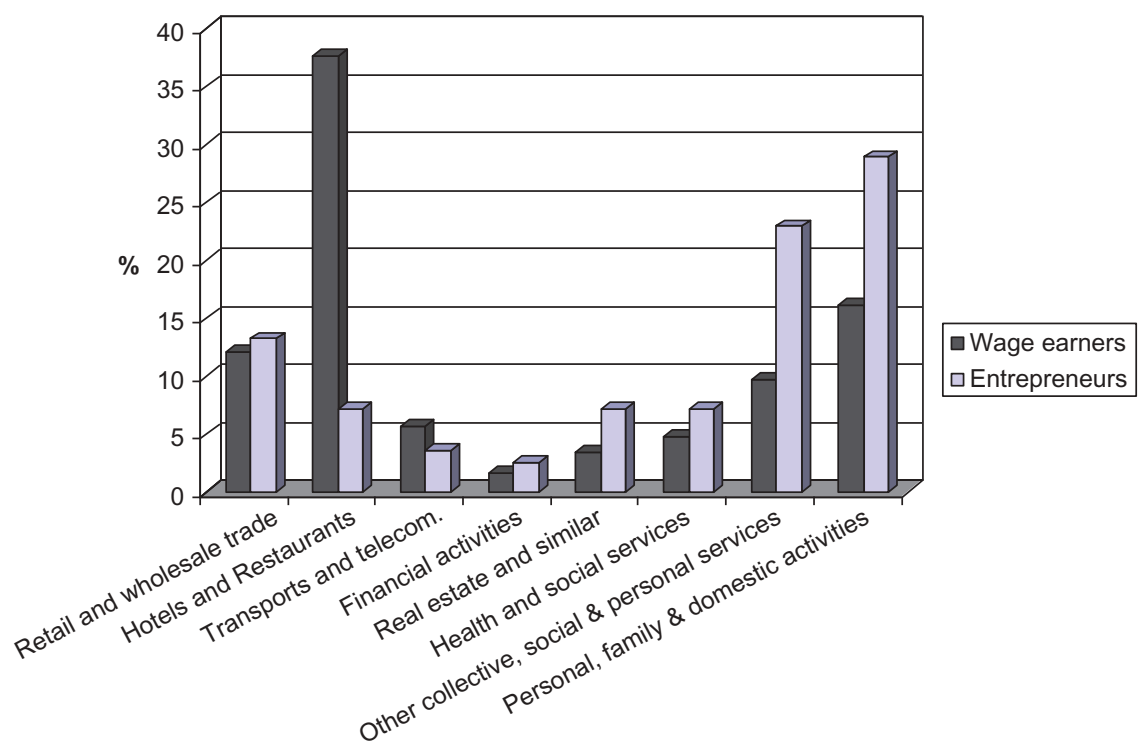

Figure 2. Active Brazilian women by activity branch (wage earners or entrepreneurs). Source: Project Vagas Atlânticas (SOCIUS/CIES/CES) - Questionnaire for Brazilian immigrants in Portugal. 
corresponding to approximately $50 \%$ of the total, than when compared with Brazilian female wage earners, who work particularly in restaurants and hospitality. This difference is partially explained by the lower initial investment required for opening a business in the beauty sector, yet it may also be the result of the mobilisation of previous experiences in hairdressing or beauty salons (e.g. in Brazil or in Portugal as employees) and of aesthetic-corporal capital as a business resource in the beauty niche.

Moreover, a detailed analysis reveals that the retail and trade sector, which ranks third among business options chosen by Brazilian immigrant women, is also partially connected with beauty and body. In fact, a significant proportion of businesses in this sector are cosmetic shops or lingerie and beachwear stores, often selling products imported from Brazil. As we believe that these activities should be considered jointly in our analysis, we have taken a broader perspective of the 'beauty sector', adopting the notion of beauty filière to include services related to physical appearance, body shape and image (hair salons, spas, nail shops, manicure/pedicure), body treatments (hair and body massages and therapies, waxing, aesthetic dental treatment, among others) as well as retail stores specialising in lingerie, swimwear, sandals and cosmetics. In addition, retail and body services are frequently offered in the same business establishment, as is the case with hairdressers selling cosmetics, or beauty salons offering beauty products.

\section{Beautification embedded in female immigrants' business and the mobilisation of aesthetic-corporal capital: general elements and Brazilian specificities}

The specialisation of women immigrant entrepreneurs in the beauty filière has been identified as a common characteristic in several host countries, involving immigrants of diverse ethnic backgrounds. Le (2012) stated that beauty occupies an important place among Asian-American small businesses in the US. This is usually associated with ethnic enclaves and self-employment, although businesses are becoming more diversified and professionalised. In their survey of the Vietnamese entrepreneur community in California and Pennsylvania, Chu, Zhu, and Chu (2010) discovered that $58 \%$ of the businesses were female-owned and $91 \%$ were concentrated in the beauty industry, mainly nail and hair salons. Hence, the beauty path deserves special consideration among female immigrant entrepreneurship, and Brazilians are no exception.

Moreover, care and beauty are intimately connected. Care still remains in the hands of women, mainly immigrants (Hochschild 1983; Anthias and Mehta 2003; Harvey 2005), whilst beauty is associated with special types of care and treatments that bodies receive, underlining a very delicate aesthetic dimension: manicure, pedicure, hair or more holistic services such as massage and treatments provided in spas. Thus, the notion of beauty is embedded in the notion of care, and beauty and care are tied to the body. Coincidentally, recent feminist 
scholarship has been committed to 'bringing bodies back into theory and research' (Kang 2010, 2), whilst Fonow and Cook (1991) speak of 'new ways to think about the body'. Therefore, paraphrasing Kang, it could be added that body, beauty and care practices (hair, nails, feet, hands) are 'new ways to think about the multiple forces shaping gendered bodies' (Kang 2010, 3), becoming venues of communication and interrelations between immigrant and autochthonous women, thereby allowing for the reassessment of a number of power issues (labelling, stereotyping).

Most beauty services require a level of intimacy that implies both physical labour and the extensive management of emotions, or 'emotional labour', which means that the way labour is offered, or its 'emotional style', becomes part of the service itself (Hochschild 1983). In close relation with this, Kang introduces 'the concept of body labour to designate the provision of body-related services and management of both feelings and bodies that accompanies it' (Kang 2010, 3), which beauty services fit in with.

Beauty practices have developed into beauty industries that include complex consumption patterns and products that enhance the 'body beautiful' from head to foot, or the beauty filière according to our denomination. Body as capital is fundamental to understanding certain business and working strategies, namely those associated with the beauty filière. In general terms, the notion of capital can be read as a type of key resources that are necessary for the development of some activity. Classical forms of capital comprehend economic, cultural and social capital, as synthesised by Bourdieu. Whilst economic capital corresponds to land and physical means of production, and social capital to quality and density of the networking relations of an individual or group (Bourdieu 1980), cultural capital comprehends the usual elements classified by economists as human capital (skills, education, experience, etc.) (Hakim 2011) combined with cultural goods and cultural knowledge, in other words 'cultivation' (Bourdieu 1986). Actually, Bourdieu refers to an 'embodied state' (Bourdieu 1986, 48) of cultural capital asserting that, 'Most of the properties of cultural capital can be deduced from the fact that, in its fundamental state, it is linked to the body and presupposes embodiment' (Bourdieu 1986, 47). However, by claiming that this form of cultural capital cannot be dissociated from the body, Bourdieu is not referring to physical characteristics or beauty, but instead uses them as an analogy for embodied cultural capital as the acquisition and accumulation process involved in obtaining cultural knowledge that cannot be dissociated from the person. In addition, cultural capital is visible through body expressions, such as the use of language and phonetic accent, physical and gestural attitudes in public or even the choice of clothes (Bourdieu 1986). Therefore, the notion of embodied cultural capital provides a point of departure for the idea of aesthetic-corporal capital posited in this text, even though its failure to consider body aesthetics and physical beauty may render it somewhat insufficient.

Aesthetic-corporal capital is in fact more in line with the idea of erotic capital conveyed by Hakim (2011). According to this author, erotic capital, which we 
can read as the capacity to seduce, involves a combination of six elements (beauty, sexual attractiveness, social interaction skills, liveliness, social presentation, sexual competence) that form the basis for the development of an attraction effect in relation to other members of society (Hakim 2011). Despite the commonalities between this perspective and the notion of aesthetic-cultural capital, there are two elements that justify the use of a narrower and more specific concept. First, because we wish to highlight physical and liveliness dimensions, devaluating social elements and sexuality per se, which are an integral part of Hakim's notion; second, due to our assumption that aesthetic-corporal capital must be applied within an analysis that departs from negative attributes (stereotypes, prejudices) that are transformed into business assets rather than a series of resources. In other words, we wish to highlight the process in relation to resource construction.

For Bhabha (1983, 22), stereotype is a 'complex, ambivalent, contradictory mode of representation, as anxious as it is assertive'. The specialisation of women immigrants in beauty filière businesses, deliberately targeting a larger clientele rather than building up an ethnic niche, may imply a process of mobilisation and transformation of stigmatic elements into positive business resources such as the aesthetic-corporal capital described earlier.

Concerning the case of Brazil, the body as capital is fundamental to understanding Brazilian culture, in which the body has become central and recurrent 'as an object of desire ... The most interesting of all is that "the body" usually is referred to unaccompanied by an adjective; it is as if it were an autonomous, abstract, independent, entity' (Goldenberg 2011, 221). Thus, extrapolating from Goldenberg's idea, it can be noted that the centrality of the body and its relation to beauty is perceived and enforced as Brazilian traits, even if naturalising and essentialising the notion. Goldenberg refers to Mauss' conception of prestigious imitation in order to explain how people arrive at ideas about bodies, stating that 'there is a cultural construction of the body, which involves the valuing or devaluing of certain attributes and behaviours so that each society has its typical body' (Goldenberg 2011, 224).

Beautification is seen as a trend in Brazilian society, mirrored in the beautyindustry boom, which has increased employment in beauty services (Edmonds 2002) and stimulated vanity among Brazilian women, leading to a substantial increase in beauty-related products and services. The 'obsession' with beautybody deserves two types of considerations. One is that the inclination of female Brazilian immigrants to beauty businesses pre-exists migration and seems to be embedded in the Brazilian culture of body aesthetics (Goldenberg 2011). Second, the use of and recourse to beauty-body as a form of capital perceived as natural lead women to believe that their Brazilianness is what makes them knowledgeable and experts in beautification. In other words, beauty is a national Brazilian myth which becomes true in the eyes of the beholder.

However, the image of the beautiful, sensual and perfect body of Brazilian women transcends the Brazilian community and is also held by the Portuguese. 
In addition, this image is not only transnationalised but, through glocalisation, acquires a highly specific meaning in the case of Portugal. The revival of colonial imaginaries turns this ideal of beauty and body into an object of desire for both Portuguese and Brazilian women, simultaneously globalising and glocalising this market niche.

This path is complex. In Portugal, the body culture found among Brazilians is in line with the colonial imaginary that traditionally portrayed Creole/colonised women, today represented by Brazilian women as exotic, sensual, sexy or even 'easy'. These images are embedded in a notion of a tropical and exuberant nature as well as in a femininity that assigns two main attributes to Brazilian women, namely the free exercise of their sensuality and physical beauty. This notion, rooted in Portuguese colonialism, enforced the hyper-sexualisation of the colonised/enslaved woman (Castelo 1998; Padilla 2007b). According to Castelo (1998), colonialism has survived until the present day, perpetuating the idea that Portuguese are immune to racism and predisposed to living together with other peoples. Gilberto Freire's Lusotropicalism, considered to be at once a supposedly scientific interpretation and a Portuguese version of colonialism, illustrates the 'coloniality of power' (Grosfoguel and Georas 2000; Quijano 1998) that imposed a pervasive gender hierarchy, denigrating women by sexualising their image.

The stereotyped image of Brazilian women, linked to the more recent body and beauty culture, has been used against women, as suggested by Naomi Wolf (1991). Stereotypes have become the basis for generalised discrimination, as they are often seen as 'man-hunters', 'husband-robbers', depraved or prostitutes (Padilla 2007a, 2007b, Pontes 2004). Simultaneously, the host society does not remain indifferent to the Brazilian body and aesthetics culture spread by the media, the telenovelas and the live transmissions of Rio de Janeiro Carnival. This process of diffusion stimulates the appetite for 'Brazilian beauty', particularly among Portuguese women, as the ideal model for the consumption of Brazilian aesthetics found in 'sexy' beach-clothes, underwear, body and nail treatments and hairdressing.

Conscious of the stereotypes but aware of the admiration that the 'Brazilian' body-beauty provokes in the imaginary and desire of Portuguese women, Brazilian women in Portugal enhance the sense of exceptionalism and quality of Brazilian aesthetic techniques, which are responsible for providing smooth skin, soft shiny hair as well as perfect nails and bodies. All these elements fit in with contemporary mainstream ideals of feminine beauty. Thus, Brazilian immigrant women start from a stereotyped image, yet reject its negative connotation whilst retaining the valuable aesthetic content of the original image. Accordingly, Brazilian female entrepreneurs send the message that body-beauty is a specific Brazilian product, in which they are the most competent crafters in order to produce and offer it in the Portuguese market. On the one hand, Brazilian women possess and retain their beauty, and on the other hand, Portuguese women may gain access to Brazilian-like beauty. Through this process, stigma is reinterpreted 
and transformed into a business resource, namely the aesthetic-corporal capital that has contributed to sustaining entrepreneurial initiatives of Brazilian immigrants from the late 1990 s until the present day.

\title{
4. Stigma and stereotypes versus the beauty myth: where does Brazilian entrepreneurship fit in?
}

Bhabha's notion of stereotype presented at the beginning of Section 3 is useful for framing stereotypes within postcolonial racism, which operates at the level of discourse and identification (Hooks 2005). Thus, Brazilian colonised women were hyper-sexualised and oppressed through eroticised relations of racial and class subordination, yet it was the mulata who embodied the 'natural' Portuguese miscegenation (Ribeiro 1994). These hierarchies valued mulatas (mixed) and Blacks (non-mixed) differently. More recently, the stereotype has been recreated, enforcing a mulatisation process whereby all Brazilian women are perceived as mulatas (namely possessing mulata attributes: sensual, hot, sexy, desirable and with desire). In addition to mulatisation, the essentialisation of Brazilian identity has also embraced attributes such as happiness, joy and sensuality that are gender-sensitive because they function differently for men and women (Padilla 2007a; Machado 2010). Due to gender asymmetries, men can benefit from these images whilst women are stigmatised, so performing 'Brazilianness' is genderised and racialised, as the following narratives illustrate:

\begin{abstract}
A Brazilian blonde has a bit of whiteness, a brunette has happiness to share, but Blacks are completely out. I used to have an Afro-Brazilian working as an aesthetic specialist, she was a good professional, but was very discriminated against; clients did not want to be served by her. (Beauty Salon owner, Algarve)

(Portuguese) people discriminate due to colour, physical appearance, social condition ... Brazilian women have a different code for dressing, talking .... This can cause discrimination sometimes. They can be misunderstood. (Dental clinic, Lisbon Metropolitan Area (LMA); author emphasis)
\end{abstract}

Sexualisation and eroticisation are predominant in the discourse, crossing colour lines and emphasising gender. Nevertheless, several women internalised the stereotype, blaming the victim, as narratives indicate:

For Portuguese, Brazilian women in Portugal are prostitutes. But many Brazilians worsen the situation ... they work as prostitutes ... they really go after men, married or not. And because of these, we are all blamed. Sometimes, I am ashamed to be a Brazilian here. (Cosmetic and sewing products shopkeeper, LMA)

Brazilian women have also created this reputation because, really, there are a lot of Brazilian women that come to Portugal to prostitute themselves; but I do not look like the typical Brazilian .... (Hairdresser, Porto) 
Nevertheless, Brazilian women in general reject this generalised and stereotyped image. Instead, they stress diversity, choosing to adopt specific aspects of the stereotype, mainly those related to dress code, body gesture and embodying beauty, as constituent parts of 'culture' or even personhood:

Brazilian women are great fighters; they struggle for their own work and don't want to be dependent on their husbands at home. However the Portuguese people have a bad image of Brazilian woman and judge us without knowing us. The Portuguese easily put a label on people and with Brazilian women this is far too generalized. People think we are all whores and do not know anything; they think we are lazy and illiterate, when actually quite the opposite is true. (Hairdresser, Leiria, Centre of Portugal)

I know that many Brazilian women came to Portugal to work in prostitution but also many Portuguese and women from other nationalities work in the field. Why has only this become widespread with the Brazilian woman? I think it's because we are more extrovert and because we are accustomed to wearing less clothing than you, but you cannot recriminate it; it is our culture, we will not change just because the Portuguese are more conservative. (Owner of body aesthetics clinic, Porto)

In colonial discourse, stereotypes represent a strategy that functions at two different levels: discursive and identification. At the discursive level, it exaggerates the difference between Portuguese and Brazilian women, but affects both. Brazilians are seen as whores but are also beautiful, whilst Portuguese are neither whores nor beautiful, but need help from Brazilians to access beautification. At the identification level, stereotypes operate through vacillation between what is in place and known and what needs to be repeated (Bhabha 1983) to differentiate between Portuguese and Brazilian women, leading to ambivalence. However, for Bhabha, the importance of identification needs to be shifted into subjectification by focusing on how colonised Brazilian women overcome stereotypes from their position of otherness or alterity. Brazilian women in Portugal are associated with negative images (prostitutes, 'man-hunters') but ambivalence is embedded in those images, in terms of how to overturn stereotypes and how to reverse them in a positive way. Therefore, Brazilian women appropriate beauty and body as ethnic aesthetic assets that become crucial to success in the beauty-related businesses. Through this process, stigmatic elements are transformed into aesthetic-corporal capital.

Nevertheless, this shift does not work equally for all Brazilian women. Intersectionality is crucial in understanding different aspects of this complex process. Recent feminist theorising has pointed that there are different layers or forms of stratification that should be considered together and in relation to each other in order to uncover the real domination matrix (Hill Collins 2000) as well as the nuances that the migration experience adds to subjectivity. Race, class and gender, ethnicity/nationality (in this case, the condition of Brazilian immigrants) and the possibility of manipulating aesthetic corporal capital are intertwined categories, yet which work separately to shape the experience of oppression or 
the multidimensionality of marginalised subjects (Crenshaw 1989). As a result, Brazilian female entrepreneurs in the beauty filière have successfully used this stereotype in their favour.

\subsection{Brazilian entrepreneurship: beauty and body at home and abroad}

As we have shown, Brazilian female entrepreneurs in Portugal have specialised in the beauty filière, maximising the general and specific qualities and attributes assigned to Brazilians: from being happy and cheerful (Machado 2010), to being beautiful, sexy and exotic (Pontes 2004; Padilla 2007a, 2007b), with well-defined corporalities that embody desirability.

Rodrigues argues that the "presence of entrepreneur immigrant women in the beauty industry lays on the social and institutional broader frame of gender roles and gender relationships, which define not only the supply, but also the demand trends of the market' $(2010$, iii). This suggests a complex configuration of the way Brazilian ethnicity and gender are played out in Portuguese society. Consequently, the way Brazilian women are seen, when overcoming the sexualised stereotype, enables some of them to develop strategies that benefit from the aesthetic-corporal capital, turning it into a comparative advantage that is essential for the beauty business.

The beauty business may be linked to both opportunity and necessity, depending on whether Brazilian women feel they can develop a business or are forced to, and whether they like and enjoy the niche, or are expected to do so. The beauty sector has been identified as a sector with fewer limitations in terms of qualifications and skills, especially because the business is mostly learned through previous employment socialisation (Chu, Zhu, and Chu 2010). In the case of Brazilian female entrepreneurs involved in the beauty sector in Portugal (a part of the beauty filière), 13 out of 18 interviewees declared having previous experience in this activity in Brazil.

However, the beauty business also essentialises women, because it is perceived as naturalised and embedded in female bodies through gender socialisation, teaching women to be feminine by adopting a visually and behaviourally womanly appearance. Thus, involvement in this sector has been a predominant female strategy.

On the one hand, most Brazilian women in the beauty filière believe that beauty comes naturally to them and is appreciated by Portuguese men and envied by Portuguese women. On the other hand, this naturalisation of beauty is also associated with negative images and prejudices existing in Portugal. Therefore, 'Brazilian beauty', explored as a key business resource, may be attained in two different ways: by ascribed or achieved statuses. One view perceives beauty in Brazilian women as ascribed to and associated with their body and personality features, as the following statements illustrate: 
Brazilian women are more exotic and different from Portuguese women, so they are more subjected to hearing malicious flattery, 'piropos', in the street. I think that for being so different from Portuguese women, Portuguese men like Brazilian women better .... (Lingerie shopkeeper, Leiria (Centre of Portugal))

Brazilian women like to call people's attention to themselves, even without knowing it. We are happier and talkative ... so sometimes we are misunderstood. (Beauty shop owner, LMA)

A second view of Brazilian beauty indicates that it is produced as a practice that is transversal to social classes, involving the development of an aesthetic culture with the necessary associated services, as the following testimonies suggest:

At the spa, when I began to serve, Spanish but also Portuguese clients asked specifically for the massages given by Brazilians. They said that the Portuguese had to learn 'to have the right touch'. (...) In Brazil, even people (women) with low incomes frequently seek such services (massages, facials...). (Beauty clinic, Figueira da Foz (Centre of Portugal))

The Brazilian woman is very vain and demanding in relation to her beauty; she likes to take care of herself and tries always be as pretty as possible, so others notice her. The Portuguese know that we work hard in our field, and I think they believe we are the best, and that is good for business. (Manicure, LMA)

As a result, many Brazilian women entrepreneurs assume that their body culture and their degree of professional specialisation in the field are highly valued by Portuguese women, who consume services and products in their pursuit of beautification. However, this entails a certain ambivalence because physical and personality beauty is easily transformed into vulgarity and exaggeration, making Brazilian women subject to discrimination. Most women agreed that prejudice against them is due to their clothing styles: the very colourful tight clothing that catches people's eye, emphasising their body shapes. Most interviewees agreed that the decision to dress provocatively worked against women, as they tend to be confused with prostitutes or are seen as morally lax:

Brazilian women are recognized at a distance, they talk loudly, wear very tight clothes ... have a different body. These aspects are motives for being labelled negatively. (Beauty salon, Algarve)

Research has shown that most Brazilian women in Portugal have at some point been confronted with negative images and judged by the standards of stereotypes, thereby conditioning their daily lives (Padilla 2007b). In consequence, some interviewees saw their entrepreneur status not only as an accomplishment but also as a source of self-esteem. By becoming business owners, Brazilian women believe that they have acquired respect and recognition, proving the negative images wrong. In their eyes, their success attests that the host society distinguishes their hard work and dedication. 
When I opened this business, prejudices decreased. Truly, they (the Portuguese) started to look at me as having more power. (Hair salon, Leiria (Centre of Portugal); author emphasis)

Business owners are seen as enjoying a better economic status. That in itself imposes respect. So Brazilian women are no longer seen as workers ... as if immigrants were only good as employees. (Beauty expert, LMA)

Even if confronting stereotypes and negative images on a daily basis, experiences vary significantly, as intersectionality suggests. Many of those who embraced entrepreneurship manifested having experienced greater self-esteem, confidence and satisfaction. In this sense, studies that focus on the subversion of social imaginaries are crucial to advancing gender theories. One new avenue for applying intersectionality theories may lie in examining subjects who are "wholly or partially privileged' (Nash 2008) such as female immigrant entrepreneurs. Our findings suggest that experiencing privilege along particular axes (class, lighter skin colour, ethnicity or other) does not weaken the claims that intersectional identities raise (Nash 2008).

\section{Concluding remarks}

The entrepreneurial initiatives of female Brazilian immigrants in Portugal cannot be considered unique in the global context; nevertheless, we have identified a number of specificities worthy of consideration. Their overrepresentation in the beauty filière comes from both gender and ethnic aspects. The gender specificity responds to a presence in a 'female-oriented' sector where women are expected to be dominant. The ethnic specificity implies that 'Brazilianness' in the beauty filière is unique (Rodrigues 2010). This complex process is supported by elements of human capital (previous work experience, in some cases vocational training) and ethnic social capital (through co-ethnic business partnerships, family support or friends' resources to obtain bank loans). However, it is the mobilisation of the naturalised/essentialised and socially constructed features assumed as 'specifically Brazilian' (the beauty of Brazilian women) and their transformation into key business resources in the form of aesthetic-corporal capital, which makes the process specific.

However, 'Brazilian beauty', supported by a 'Brazilian' culture of body and aesthetics, has a paradoxical content. It is partially based on a superficial and convenient justification of prejudice and discrimination, internally shared by Brazilian women, with roots in the colonial imaginary whereby Portuguese men's fascination with 'hot', 'spicy' and sensual Creole women, represented by the Brazilian mulata, was justified in the name of the 'natural' basis of miscegenation. Nowadays, with increasing migration, a revival of the (neo)colonial discourse has gained relevance in Portuguese society, by re-establishing racial and gendered subordination patterns, in this 
case around Brazilian immigrant women and native Portuguese men. However, Portuguese women, the main clients of Brazilian entrepreneurs of the beauty sector, are also part of this web of relationships, not only because they largely reproduce prejudicial discourses but also because they have developed an ambivalent contingency relationship with Brazilian women: on the one hand, they stigmatise and differentiate through supposedly superior morality, whilst on the other hand they wish to possess the attainable Brazilian beauty and body.

Taking this into consideration, the original set of negative features associated with the image of Brazilian women also has the potential to be transformed into a valuable resource for some immigrant women. By valuing their supposedly 'specific', 'advanced' and 'natural' aesthetic and body culture, Brazilian women immigrants use the desire for 'beauty' and 'sensuality' - and its associated consumption potential - identified in the host society, to set up and develop various kinds of beauty filière businesses. The resources mobilised can be interpreted as aesthetic-corporal capital, a key element in the glocalised niche created in the Portuguese economy, which can be valued as a symbolic resource aligned to what Ong (1996) has named 'cultural citizenship'. The sense of opportunity to twist negative images into a positive resource (Piscitelli 2008) speaks of the 'agency' of these entrepreneurs, illustrating a further application of the intersectionality theory, by innovatively assessing layers of oppression and privilege simultaneously.

\section{Acknowledgement}

This article is an output of the Foundation for Science and Technology (FCT) sponsored project PIHM/GC/0111/2008 and Brazilian Entrepreneurial Links and Transnational Strategies-Women (BELTS-W).

\section{Note}

1. This project was carried out by a group of researchers from CIES (Lisbon University Institute), SOCIUS (Lisboa School of Economics and Management - Technical University of Lisbon) and CES (University of Coimbra) and for the purpose of providing an encompassing characterisation of the Brazilian population in Portugal based on data collected in a representative sample of questionnaires.

\section{References}

Anthias, F., and N. Mehta. 2003. "The Intersection between Gender, the Family and SelfEmployment: The Family as a Resource." International Review of Sociology - Revue Internationale de Sociologie 13 (1): 105-116.

Bhabha, H. 1983. "The Other Question ... Homi K. Bhabha Reconsiders the Stereotype and Colonial Discourse.” Screen 24 (6): 18-36. doi:10.1093/screen/24.6.18. 
Bourdieu, P. 1980. "Le Capital Social." Actes De La Recherche En Sciences Sociales 31: 2-3. Accessed August 2013. http:/www.persee.fr/web/revues/prescript/article/ arss_0335-5322_1980_num_31_1_2069.

Bourdieu, P. 1986. "The Forms of Capital." In Handbook of Theory and Research for the Sociology of Education, edited by J. G. Richardson. New York: Greenwood Press. Reprinted in Halsey, A. H., Lauder, H., Brown, P., Wells, A. S., eds. 1997. Education: Culture, Economy and Society, 46-58. Oxford: Oxford University Press.

Castelo, C. 1998. O Modo Português De Estar No Mundo: O Luso-Tropicalismo E a Ideologia Colonial Portuguesa (1933-1961). Porto: Afrontamento.

Chu, H., L. Zhu, and A. Chu. 2010. "Immigrant Business Owners: A Case Study of Vietnamese Entrepreneurs in America." Journal of Business and Entrepreneurship 22 (2): 60-74.

Crenshaw, K. 1989. "Demarginalizing the Intersection of Race and Sex: A Black Feminist Critique of Antidiscrimination Doctrine, Feminist Theory, and Antiracist Politics." University of Chicago Legal Forum 139: 139-168.

Dallalfar, A. 1994. "Iranian Women as Immigrant Entrepreneurs." Gender \& Society 8 (4): 541-561. doi:10.1177/089124394008004005.

Edmonds, A. 2002. "No Universo Da Beleza: Notas De Campo Sobre Cirurgia Plástica No Rio De Janeiro.” In $\mathrm{Nu} \&$ Vestido: Dez Antropólogos Revelam a Cultura do Corpo Carioca, edited by M. Goldenberg, 189-261. Rio de Janeiro: Record.

Esteves, M. C., org. 1991. Portugal, País De Imigração. Lisbon: Instituto de Estudos para o Desenvolvimento.

Fonow, M. M., and J. A. Cook, eds. 1991. Beyond Methodology: Feminist Scholarship as Lived Research. Bloomington: Indiana University Press.

Fonseca, M. L., J. Malheiros, A. Esteves, and M. J. Caldeira. 2002. Immigrants in Lisbon Routes of Integration. Lisbon: EPRU/CEG.

Goldenberg, M. 2011. "The Body as Capital: Understanding Brazilian Culture." Vibrant 7 (1): $220-238$.

Grosfoguel, R., and C. S. Georas. 2000. “'Coloniality of Power' and Racial Dynamics: Notes Towards a Reinterpretation of Latino Caribbeans in New York City." Identities 7 (1): 85-125. doi:10.1080/1070289X.2000.9962660.

Hakim, C. 2011. Erotic Capital. the Power of Attraction in the Boardroom and the Bedroom. New York: Basic Books.

Harvey, A. 2005. "Becoming Entrepreneurs: Intersections of Race, Class and Gender at the Black Beauty Salon." Gender \& Society 19 (6): 789-808. doi:10.1177/ 0891243205280104.

Hill Collins, P. 2000. Black Feminist Thought. 2nd ed. New York: Routledge.

Hochschild, A. 1983. The Managed Heart: the Commercialization of Human Feelings. Berkeley: University of California Press.

Hooks, D. 2005. "The Racial Stereotype, Colonial Discourse, Fetishism, and Racism." The Psychoanalytic Review 92 (5): 701-734. doi:10.1521/prev.2005.92.5.701.

Ionescu, D. 2004. "Women Entrepreneurship: A Second Best Solution?" Finance \& Bien Commun 20: 79-90. doi:10.3917/fbc.020.0079.

Kang, M. 2010. The Managed Hand: Race, Gender and the Body in Beauty Service Work. Berkeley: University of California Press.

Le, C. N. 2012. "Asian Small Businesses." Asian-Nation: The landscape of AsianAmerica. Accessed April 2012. www.asian-nation.org/small-business.shtml

Levent, T. B., E. Masurel, and P. Nijkamp. 2003. Gender Differences in Ethnic Entrepreneurship. Jyväskylä: European Regional Science Association.

Levent, T. B., and P. Nijkamp. 2006. Migrant Female Entrepreneurship: Driving Forces, Motivation and Performance. Amsterdam: Faculty of Economics and Business Administration, Vrije Universiteit Amsterdam. 
Machado, I. J. R. 2010. Cárcere Público: Processos De Exotização Entre Imigrantes Brasileiros No Porto. Lisbon: ICS.

Malheiros, J. 1997. "Indians in Lisbon: Ethnic Entrepreneurship and the Migration Process." In Southern Europe and the New Immigrations, edited by R. King and R. Black, 93-112. Brighton: Sussex Academic Press.

Malheiros, J., org. 2007. A Imigração Brasileira Em Portugal. Lisbon: Observatório da Imigração/ACIDI.

Malheiros, J., B. Padilla, and F. Rodrigues. 2010. Mulheres Imigrantes Empreendedoras em Portugal. Lisbon: Comissão para a Cidadania e Igualdade de Género.

Menjívar, C. 1999. "The Intersection of Work and Gender." American Behavioral Scientist 42 (4): 601-627. doi:10.1177/00027649921954381.

Morokvasic, M. 1984. "Birds of Passage are Also Women." International Migration Review 18 (4): 886-907. doi:10.2307/2546066.

Nash, J. 2008. "Re-Thinking Intersectionality.” Feminist Review 89: 1-15. doi:10.1057/ fr.2008.4.

Oliveira, C. R. 2005. Empresários De Origem Imigrante, Estratégias De Inserção Económica Em Portugal. Lisbon: ACIME.

Oliveira, C. R. 2008. "Determinantes Das Estratégias Empresariais De Imigrantes Em Portugal." Migrações 3: 109-138.

Ong, A. 1996. "Cultural Citizenship as Subject-Making: Immigrants Negotiate Racial and Cultural Boundaries in the United States." Current Anthropology 37 (5): 737-762. doi:10.1086/204560.

Padilla, B. 2007a. "A Imigração Brasileira Em Portugal: Considerando O Género $\mathrm{Na}$ Análise." In A Imigração Brasileira Em Portugal, edited by J. Malheiros (org.), 113-134. Lisbon: ACIDI/Observatório da Imigração.

Padilla, B. 2007b. "Brasileras En Portugal: De La Transformación De Las Diversas Identidades a La Exotización." Amérique Latine Histoire et Mémoire. Les Cahiers ALHIM, No 14. Accessed February 2012. http://alhim.revues.org/ index2022.html.

Padilla, B. 2008. "O Empreendedorismo Na Perspectiva De Género: Uma Primeira Aproximação Ao Caso Das Brasileiras Em Portugal." Migrações 3: 181-204.

Pajnik, M., and G. Campani, eds. 2011. Precarious Migrant Labour across Europe. Ljubjana: Peace Institute.

Pearce, S. C. 2005. "Today's Immigrant Woman Entrepreneur: The Diversity Factor." New Frontiers 13 (3): 23-29.

Peixoto, J. 2008. "Limites E Oportunidades Do Empreendedorismo Imigrante." Migrações 3: 305-307.

Piscitelli, A. 2008. "Interseccionalidades, Categorias De Articulação E Experiências De Migrantes Brasileiras." Sociedade E Cultura 11 (2): 263-274. doi:10.5216/sec. v11i2.5247.

Pontes, L. 2004. “As Mulheres Brasileiras na Mídia Portuguesa.” Cadernos Pagu (23): 229-256. doi:10.1590/S0104-83332004000200008.

Quijano, A. 1998. "La Colonialidade Del Poder Y La Experiencia Cultural Latinoamericana." In Pueblo, Época Y Desarrollo: La Sociología De América Latina, edited by R. Briceño-Leon and H. R. Sonntag, 139-155. Caracas: Nueva Sociedade.

Ribas-Mateos, N., and L. Oso. 2005. "Filipinas in Spain: Learning to Do Domestic Labour." In Asian Migrants on the European Labour Markets, edited by E. Spaan, et al., 159-176. London: Routledge.

Ribeiro, O. 1994. A Originalidade Da Expansão Portuguesa. Lisbon: Ed. João Sá da Costa. 
Rodrigues, F., 2010. "A 'Beleza' Das Mulheres Imigrantes Empreendedoras.” Master's thesis. FCSH, Universidade Nova de Lisboa. Accessed April 2012. http://run.unl.pt/ bitstream/10362/4818/1/Frederica\%20Rodrigues.pdf.

Rodrigues, F., B. Padilla, and J. Malheiros. 2011. "A Dimensão Psico-Social Do Empreendedorismo Imigrante Feminino.” Migrações 8: 93-122.

SEF (Serviço de Estrangeiros e Fronteiras). 2012. Relatório de Imigraçõa, Fronteiras e Asilo-2013. Lisbon: SEF.

Serdedakis, N., G. Tsiolis, M. Tzanakis, and S. Papaioannou. 2003. Strategies of Social Integration in the Biographies of Greek Female Immigrants Coming from the Former Soviet Union: Self-Employment as an Alternative. International Review of Sociology - Revue Internationale de Sociologie 13 (1): 145-162.

Wolf, N. 1991. The Beauty Myth: How Images of Beauty are Used against Women. New York: William Morrow.

JORGE MALHEIROS is Associate Professor in the Institute of Geography and Spatial Planning at the University of Lisbon.

ADDRESS: Institute of Geography and Spatial Planning, University of Lisbon, Edifício IGOT, R.Prof. Gama Pinto, 1649-003 Lisboa, Portugal.

Email: jmalheiros@campus.ul.pt

BEATRIZ PADILLA is Associate Professor in the Social Science Institute at the University of Minho.

ADDRESS: Social Science Institute, Sociology Department, University of Minho, CICS, Campus Gualtar, 4710-057 Braga, Portugal.

Email: padilla.beatriz@gmail.com 